\title{
Bed planting for resource conservation, diversification and sustainability of wheat based cropping system
}

\author{
Subhash Chandra Tripathi ${ }^{1}$ and Anup Das ${ }^{2}$ \\ ${ }^{1} I C A R$-Indian Institute of Wheat and Barley Research, Karnal, Haryana, India \\ ${ }^{2}$ ICAR- Research Complex for North East Hill Region, Barapani, Meghalaya, India
}

\section{Article history}

Received: 11 July, 2016

Revised : 02 February, 2017

Accepted: 15 May, 2017

\section{Citation}

Tripathi SC and A Das. 2017. Bed planting for resource conservation, diversification and sustainability of wheat based cropping system. Journal of Wheat Research 9(1):1-11. doi.org/10.25174/2249-4065/ $2017 / 62285$

*Corresponding author
Email: subhtripathi@gmail.com

(C) Society for Advancement of Wheat and Barley Research

\begin{abstract}
Sustainability of rice-wheat cropping system has been at threat mainly due to declining groundwater levels, soil organic matter content and macro and micro-nutrient availability, increased soil salinization, incidence of diseases and pests. In recent past a number of resource conservation technologies (RCTs), like zero-tillage, bed planting, laser leveling, intercropping of high value crops in the systems, have been introduced in the rice-wheat cropping system in India. Among them bed planting technique holds potential for efficient resource conservation, diversification as well as for sustainability of rice-wheat cropping system. The reported experimental results indicated that bed planting technique not only save the resources like water $(20-40 \%)$, nutrients $(25 \% \mathrm{~N})$ and labour but also facilitates the greater diversification and intensification of the rice-wheat cropping systems. Adoption of this system also increased the production of cereals $(6-37 \%)$, pulses $(15-34 \%)$ and oilseeds $(20 \%)$ over flat planting. This system of planting also offers opportunity for intercropping viz. wheat + sugarcane, wheat + mentha, maize + mung bean/ urd bean etc. that provides higher productivity and income from the system. In this paper importance of bed planting technique in conservation of natural resources and diversification/intensification of rice-wheat cropping system has been described.
\end{abstract}

Keywords: Diversification, intensification, input use efficiency, resource conservation, water saving

\section{Introduction}

In South Asia, rice (Oryza sativa L.)-wheat(Triticum aestivum L.) crop sequence is the largest agriculture production system and occupies about 13.5 million hectare area including 10.3 million hectare in India, extending from IndoGangetic plains (IGP) to Himalayan foothills (Gupta et al., 2003; Ladha et al., 2000; Timsina and Connor, 2001). Rice and wheat contribute $75.56 \%$ of total food grain production in the country during 2016-17. In India, approximately $23.6 \%$ and $33.8 \%$ of total rice and wheat area, respectively, is represented by rice-wheat system alone, which requires contrasting edaphic conditions. Rice is generally transplanted in puddled soil and is given continued submergence whereas wheat is grown in upland well-drained soils having good tilth. Continuous adoption of this system has been reported to decline soil and crop productivity (Nambiar and Abrol, 1989). Analysis of several long-term experiments on rice-wheat (Duxbury et al., 2000 and Yadav et al., 1998) indicated a negative average yield trend of rice $(-0.02 \mathrm{t} / \mathrm{ha} / \mathrm{yr}$ or $0.5 \% / \mathrm{yr})$.

The gradual setting of environmental degradation is compounding the problem, early signs of which are becoming visible throughout the rice-wheat farming systems as most countries move into the post green revolution era (Cassman and Pingali, 1993). It is argued that the stagnating or declining yields in both research station and farmers' fields, declining factor productivity 
and degrading soil and water resources are threatening the sustainability of this system (Hobbs and Morris, 1996; Duxbury et al., 2000; Ladha et al., 2003). An agricultural system is regarded as sustainable if the biophysical and socio-economic objectives of it are met, therefore, it is essential that performance of the system be continuously monitored for productivity and natural resources to ensure and improve sustainability (Powlson et al., 1998). The growing realization that the agriculture of the post-green revolution era will be guided by the need to produce more quality food from the same land and water resources, besides sustaining environmental quality, only adds to the challenge. The major disadvantages of flat planting under irrigated condition are (i) water management by flood irrigation not only results in wastage of water, but also can cause soil surface crusting, (ii) the increase of crop production levels that have occurred with flat planting combined with flood irrigation and increase in $\mathrm{N}$ application has led to increasing crop canopy humidity, with corresponding increases in the incidences of the disease and pest, (iii) flat planting does not provide opportunity for intercropping for the crops requiring differential moisture regime and (iv) crop lodging can be higher under flat planting as there is no passage of air movement (Sayre and Moreno Ramos, 1997, Tripathi et al., 2002). The major challenge, therefore, is to develop an alternative system that produce more without deteriorating resource base and improve profitability and sustainability. Adoption of RCTs like bed planting could answer the major constraints to the sustainability issues of rice-wheat system (Table 1).

Table 1. Multiple benefits of bed planting technology

\begin{tabular}{|c|c|c|c|}
\hline $\begin{array}{l}\text { Crop diversification } \\
\text { and intensification }\end{array}$ & Higher productivity & Resource conservation & Eco-friendly \\
\hline $\begin{array}{l}\text { Inclusion of cereals, } \\
\text { legumes and oilseeds. } \\
\text { Inclusion of vegetable } \\
\text { pea and green manure } \\
\text { crops. } \\
\text { Inclusion of sugar- } \\
\text { cane and mentha in } \\
\text { furrows. }\end{array}$ & $\begin{array}{l}\text { Bolder grains. } \\
\text { Less problem of weeds, pest and dis- } \\
\text { eases. } \\
\text { Better condition of plant micro environ- } \\
\text { ment. } \\
\text { Reduce lodging. } \\
\text { Facilitate easy intercultural operation. } \\
\text { Facilitate farm mechanization. } \\
\text { Manual and easy rouging. } \\
\text { Higher farm income. } \\
\text { Year round employment } \\
\text { Increased cropping intensity. }\end{array}$ & $\begin{array}{l}\text { Save irrigation water by } 20-40 \% \\
\text { Reduce cost of irrigation. } \\
\text { Save fertilizer N by } 25 \% \text {. } \\
\text { Save up to } 40 \% \text { diesel in perma- } \\
\text { nent bed planting. } \\
\text { Reduce seed requirement by } 25 \% \text {. } \\
\text { Reduce cost of cultivation by } \\
20 \% \text {. Higher input use efficiency. } \\
\text { Better nutrient cycling through } \\
\text { improved residue management. } \\
\text { Facilitate timely sowing of crops } \\
\text { in sequence. }\end{array}$ & $\begin{array}{l}\text { Reduce } \mathrm{CO}_{2} \text { emission } \\
\text { by } 18-19 \% \text {. } \\
\text { Improve aeration by } \\
\text { providing easy drain- } \\
\text { age. } \\
\text { Improve soil physico- } \\
\text { chemical properties } \\
\text { Groundwater pollu- } \\
\text { tion and emission of } \\
\text { methane expected to } \\
\text { decrease. } \\
\text { Reduced use of pesti- } \\
\text { cides. }\end{array}$ \\
\hline
\end{tabular}

\section{Bed planting technique}

Bed planting is a system in which crops are sown on ridges, used to form the raised beds of appropriate dimension, seeding and placing the fertilizer in one go. The height of the beds is maintained at about 15 to $20 \mathrm{~cm}$ with a dimension of about $65-70 \mathrm{~cm}$. Generally crops are seeded on the top portion of bed ( $35 \mathrm{~cm}$ width) and in case of wheat three rows having a distance of $17 \mathrm{~cm}$ apart are sown. The furrow width is generally $30-35 \mathrm{~cm}$ and is used for irrigation, drainage, operating tools for weeding and other intercultural operations. Some time additional crops like sugarcane, mentha, raddish and turnip etc can be grown in furrows. The furrow area can be better called as input management zone and ridge or bed area as crop management zone. Alternate ridges and furrows reduces runoff, improves percolation, increases the surface area for capturing rainfall and facilitates drainage in case of excess rainfall (Sayre and Moreno Ramos, 1997). In India, most of the oilseed and pulse crops are grown on flat by broadcasting with flood irrigation and/or under continental monsoonal type climate resulting in low productivity. Generally, these crops are susceptible to water stagnation, experienced during rainy season or flood irrigation. In this regards bed planting techniques have a lot of advantage, which could be helpful in diversification of rice-wheat system. In Mexico a single row is planted on top of each bed for row crops like maize, soybean, cotton, sorghum, safflower and dry bean; 1-2 rows per bed are planted for crops like chickpea and canola; but 2-4 defined rows, spaced 15-30 $\mathrm{cm}$ apart depending on bed width, are used for wheat. Even though most farmers still use conventional tillage, remaking the beds for each new crop, those farmers grow wheat on beds obtain about $8 \%$ higher yields, use approximately $25 \%$ less irrigation water and encounter at least $25 \%$ less operational costs as compared to conventional tilled wheat on the flat planting

(Aquino, 1998). cides. 
The major thrust of bed planting is to enhance the productivity and save the irrigation water. In the last few decade in other parts of the world like high-yielding, irrigated wheat-growing area of north-western Mexico (Sayre and Moreno Ramos, 1997) where bed planting rose from 6 to $75 \%$ among farmers. The use of raised beds for the production of irrigated non-rice crops was pioneered in the heavy clay soils of the rice growing region in Australia in the late 1970s (Maynard, 1991), and for irrigated wheat in the R-W areas of the IGP during the 1990s, inspired by the success of beds for wheat-maize systems in Mexico (Sayre and Hobbs, 2004). Potential agronomic advantages of beds include improved soil structure due to reduced compaction through controlled trafficking, and reduced water logging and timelier machinery operations due to better surface drainage. In India, bed planting also creates the opportunity for mechanical weed control and better fertilizer placement. Permanent beds also provide the opportunity for diversification to water logging sensitive crops not suited to conventional flat planting. There are several reports of reduced irrigation amounts or time, with similar or higher yields, for wheat on beds compared with conventional tilled wheat. Typical irrigation savings range from 18 to 30\% (Hobbs and Gupta, 2003). Based on positive interactions through visits of scientists from developing countries to the CIMMYT base agronomy program, bed planting of wheat has also been introduced in various other countries. Work has also started in South Africa, Morocco, Sudan, Iran, Kyrgyzstan, Uzbekistan and Nepal. Water savings are significant for wheat and range from $25-35 \%$, which is an extremely crucial issue in these countries, which are reliant on irrigation water as competition for water between urban and rural areas intensifies. These results are from trials that form part of a collaborative program with CIMMYT to extend wheat bed planting to China and other countries. It is extremely interesting to observe the marked reduction in two serious wheat diseases, sharp eyespot and powdery mildew with bed planting which is likely the consequence of modest plant canopy micro-climatic differences resulting from the change in plant orientation (Wang et al., 1999).

\section{Permanent bed planting system}

The benefit of bed planting becomes more prominent when beds are 'permanent' that is maintained as such over the longer duration and reshaped as and when required. Passing a shovel down the furrows reshapes the beds. The next crop is planted into the stubble in the same bed. This technology besides reducing the cost of cultivation also maintains the soil health. In this system extensive tillage operations are performed for the preparation of beds for the first crop and there after for succeeding crops only sowing and reshaping is done. The retention of crop residue helps in improving the physico-chemical and biological properties of the soil thereby providing the deeper rooting and better soil, water and air relationships. Use of permanent beds helps in reducing the turn around time and thereby increases the cropping intensity.For cropping systems like cotton-wheat, soybean-wheat, pigeon pea-wheat, sorghum-wheat and maize-wheat $e t c$. both the crops can be raised on the same beds involving single tillage operation. Sayre and Hobbs (2004) reported higher productivity with continuous crop residue retention followed by conventional tillage with residue incorporation, permanent bed treatments with full removal and lowest yield in with residue burning. A considerable increase in grain yield of maize with bed planting (5.66 t/ha) compared to flat no-till (4.75 t/ha) and conventional till (4.39 t/ha) planting systems, respectively was reported by Jat et al. (2005). Further, the water productivity $\left(\mathrm{kg}\right.$ grain $/ \mathrm{m}^{3}$ water) of either crop of maize and wheat was remarkably higher in bed planting (2.79 and 1.98) followed by no-till (1.74 and 1.89 ) and the lowest (1.36 and 1.38) in conventional till system. Permanent beds with residue retention also result in lower run off and soil erosion, and better soil structure in 0-15 cm depth (Hulugalle et al., 2007).

\section{Beds for diversification of rice-wheat system}

Different crop sequences were studied under bed planting at Karnal with focus to diversify/intensify the rice-wheat system. In this planting system, crops were grown on the top of $35 \mathrm{~cm}$ wide raised beds and irrigation was given in $35 \mathrm{~cm}$ wide furrows. Three rows of wheat, two rows of vegetable pea, green gram, mustard and one row of maize were grown on bed. Wheat after maize/vegetable pea and green gram after mustard/wheat was sown just by reshaping the beds to reduce the tillage cost. Green gram was incorporated into the soil after picking mature pods. The cost of cultivation was calculated and different crop sequences were compared by converting the yield of all the crops in a sequence into wheat equivalent yield on price basis and then averaged. Sustainability value index (SVI) was calculated as per procedure described by Singh et al. (1990). 
Rice-vegetable pea (bed)-wheat (bed)- green gram (bed) produced maximum wheat equivalent yield (15.26 t/ha) followed by rice-mustard (bed)-green gram (bed) (14.82 t/ha) both under bed planting, which were significantly higher than other crop sequences. The wheat equivalent yield of these two crop sequences approximately was $25 \%$ higher than conventional rice-wheat system (Table 2).

Table 2. Wheat equivalent yield of different crop sequences

\begin{tabular}{lc}
\hline Cropping sequences & Wheat equivalent yield (t/ha) \\
\hline CS1: Rice-wheat (Conventional) & 11.93 \\
CS2: Sorghum (Fodder) -wheat (bed)-green gram (bed) & 12.06 \\
CS3: Rice-mustard (bed)-green gram (bed) & 14.82 \\
CS4: Rice-vegetable pea (bed)-wheat (bed)- green gram (bed) & 15.26 \\
CS5: Maize (bed)- vegetable pea (bed) -wheat (bed) & 13.02 \\
CD at 5\% & 0.68 \\
\hline
\end{tabular}

Source: Tripathi and Singh (2008)

The crop sequences CS3, CS4 and CS5 under bed planting recorded 58.19, 38.9 and $36.8 \%$, higher net return, respectively than CS1 (rice-wheat system under conventional plating) (Table 3). In this study rice-vegetable pea (bed)-wheat (bed)- green gram (bed) recorded higher net return compared to the finding of Chauhan et al. (2001) where same sequence was practiced on conventional flat planting. Rice-mustard (bed)-green gram (bed) sequence showed highest sustainability value index (SVI) (0.92) which was much higher than SVI of conventional ricewheat system (0.68). Tripathi et al. (2016) also reported that intensification of rice- wheat system by including green gram on bed after wheat is the key for sustainability of the system with higher profitability.

Table 3. Economics $\left(\mathrm{Rs} / \mathrm{ha} \times 10^{3}\right)$ and sustainability value index (SVI) of crop sequences

\begin{tabular}{|c|c|c|c|c|}
\hline Cropping sequences & $\begin{array}{l}\text { Cost of } \\
\text { cultivation }\end{array}$ & $\begin{array}{l}\text { Net } \\
\text { return }\end{array}$ & $\mathrm{B}: \mathrm{C}$ & SVI \\
\hline CS1: Rice-wheat (Conventional) & 50.7 & 24.4 & 1.48 & 0.68 \\
\hline CS2: Sorghum (Fodder) -wheat (bed)-green gram (bed) & 52.1 & 23.6 & 1.45 & 0.66 \\
\hline CS3: Rice-mustard (bed)-green gram (bed) & 54.7 & 38.6 & 1.71 & 0.92 \\
\hline CS4: Rice-vegetable pea (bed)-wheat (bed)- green gram (bed) & 62.2 & 33.9 & 1.55 & 0.90 \\
\hline CS5: Maize (bed)- vegetable pea (bed) -wheat (bed) & 50.4 & 33.4 & 1.66 & 0.81 \\
\hline
\end{tabular}

Source: Tripathi and Singh (2008)

By going for bed planting farmers can easily incorporate legumes in rice- wheat system. Legume crops fix atmospheric $\mathrm{N}$ and enrich soil fertility, and could help to sustain the long-term productivity of cereal-based cropping systems. Depending on the soil and ecological stresses, the rice-wheat cropping system can be diversified using legumes as a substitute crop (Yadav et al., 1998). Consistently better productivity from rice-pulse than rice-wheat systems has been reported by Hegde (1992). The benefits of legumes in rotation includes biological nitrogen fixation, increased nutrient availability, improved soil structure, reduced disease incidence and increased mycorrhizal colonization also occur (Wani et al., 1995).
The bed planting technique provides an opportunity for crop diversity through inclusion of various crops as well as feasibility of inter or relay cropping thereby leading to resource efficient cropping systems. Pigeon pea, the most important wet season grain legume crop in south Asia has shown potential for rice crop diversification in IGP. The introduction of extra short duration pigeon pea (ICPL-88039) and bed planting technique has shown tremendous potential for increasing the water productivity and economic growth of the farmers with the limited resources (Jat and Sharma, 2005). Increased opportunities for crop diversification in both the wet and dry seasons that allow response to market opportunities as well as to the reduced supply of water for example, research at Asian Vegetable Research and Development Center (AVRDC) 
in tropical Taiwan has concluded that vegetables could be grown more profitably than rice (Kleinhenz et al., 1996) and arrest soil structural degradation and hardpan formation from intensive rice.

With the introduction and popularization of bed planting technique, farmers in India mainly in IGP are accepting a new practice of simultaneous cropping of wheat and sugarcane. In this technique, wheat is grown on beds and sugarcane in furrows. In some areas generally farmer's plant sugarcane after harvest of wheat crop (May) and the yield of late planted sugarcane is very low due to poor germination, higher weed population and shorter tillering period. Autumn sugarcane gave 25 per cent higher cane yield and higher sugar recovery than spring planted sugarcane. So to achieve higher cane yield and better returns, autumn planted cane needs special attention. Since, there is a loss of one rabi crop if sole autumn sugarcane is planted, but by intercropping system, both wheat and sugarcane can be grown successfully. In this system sugarcane had no adverse effect on wheat yield. Since sugarcane remain dormant during winter months and does not compete with wheat and a productivity level of $5.84 \mathrm{t} /$ ha in wheat and $95 \mathrm{t}$ cane/ha was recorded with autumn sugarcane + wheat system in bed technique (Singh et al., 2002b). Bed technique also provides opportunity for other intercropping viz. wheat + mentha, maize + mung bean/ urd bean etc. that provides higher productivity and income from the system. It is not possible to include intercrops in flat planting mainly due to differential water requirement and difficulties in management.

Wheat crop planted on beds produces bolder grain resulting higher thousand grain weight with lesser lodging and recorded higher productivity. Bed planting reduces lodging owing to lesser water contact on wheat culm and increase thickness of basal internodes. Bed planting increased stem weight $(8.1 \%)$, spike weight $(7.2$ $\%)$, diameter of first $(3.8 \%)$, second $(7.1 \%)$, third $(8.2 \%)$ internode and peduncle $(9.0 \%)$ as compared to flat planted crop and this lead to 70-75\% reduction in lodging score (Tripathi et al., 2002). At the same time furrow provides easy movement of air. Wheat varieties grown on bed exhibited higher yield than flat planting (Tripathi et al., 2005). A study conducted by Connor et al. (2003) in India showed that crops like maize (37.4\%), urdbean (33.6\%), mungbean $(21.8 \%)$, green pea $(14.5 \%)$, wheat $(6.4 \%)$, rice $(6.3 \%)$, pigeon pea $(46.7 \%)$ and gram $(37.0 \%)$ on bed gave higher grain yield compared to flat planting. Similar results were also obtained by Tripathi (2008).
Table 4. Comparison of yield ( $\mathrm{q} / \mathrm{ha}$ ) of different crops under bed and flat planting

\begin{tabular}{lccc}
\hline Crops & \multicolumn{2}{c}{ Planting methods } & \multirow{2}{*}{$\begin{array}{c}\text { \% increase in } \\
\text { yield over flat }\end{array}$} \\
\cline { 2 - 3 } & Bed & Flat & 34.0 \\
\hline Vegetable pea & 47.61 & 35.52 & 11.79 \\
Green gram & 21.99 & 19.67 & 20.4 \\
Mustard & 22.88 & 19.0 & 19.1 \\
Pigeon pea & 33.35 & 28.0 & \\
\hline
\end{tabular}

Source: Tripathi (2008)

\section{Genotypic requirement for the new resource conservation technologies (RCTs)}

In areas where new resource conservation technologies are gaining popularity, farmers require new cultivar for the new practice (Joshi et al., 2004). Earlier studies failed to detect variety $\mathrm{x}$ tillage practice interactions. The probable reasons for these may be of small number of genotypes tested and perhaps the fact that they were bred under conventional tillage (Trethowan and Reynolds, 2005). Significant variety x tillage interactions were reported in tests involving diverse genotypes, requiring plant breeders involved in wheat improvement to tailor the genotype to different resource conservation technologies (Sharma et al., 1997 and Sayre, 2002). Watt et al. (2005) found that some of the varieties grew best in unploughed soil. The tillage $\mathrm{x}$ genotype interactions suggests that varietal development should be targeted to new RCT requirements (Joshi et al., 2007).

Table 5. Interaction between planting method and varieties on grain yield ( $\mathrm{t} / \mathrm{ha})$

\begin{tabular}{lccc}
\hline Varieties & \multicolumn{2}{c}{ Planting methods } & \multirow{2}{*}{$\begin{array}{c}\text { Permanent } \\
\text { bed }\end{array}$} \\
\cline { 2 - 3 } & Flat & Bed & \\
\hline PBW 343 & 8.46 & 8.41 & 5.72 \\
Baviacora 92 & 8.77 & 9.47 & 7.10 \\
WH 542 & 8.82 & 8.93 & 6.13 \\
Rayon 89 & 8.08 & 8.19 & 6.09 \\
CD at 5\% & \multicolumn{2}{c}{2.45} \\
\hline
\end{tabular}

Source: Tripathi et al. (2002)

Following this approach, wheat breeders of the CIMMYT have begun to select parental lines on the basis of their performance under various tillage systems (Trethowan and Reynolds, 2005). In bed planting, there is interaction between the genotype and planting method for the yield as well as other yield attributing parameters (Sayre and Moreno Ramos, 1997; Tripathi et al., 2002 and 2005). The research work carried out at CIMMYT, Mexico by Tripathi et al. (2002) revealed that wheat cultivar PBW 343 and WH 542 produced significantly higher grain yield under bed planting compared to permanent bed planting (Table 5). 


\section{Nutrient management}

Bed planting system requires lower fertilizer $\mathrm{N}$ as compared to conventional flat system. In general, saving was observed to the tune of around 25 per cent (Sharma et al., 2007). This saving can be attributed to improved N-use efficiency owing to closer placement of the nutrients in the root zone. The close drilling of the fertilizer to crop will give higher fertilizer use efficiency as well as competitive advantage over weeds compared broadcast application. Due to better fertilizer use efficiency initially crop looks dark green color compared to flat system. In conventional methods flood irrigation is done and which in combination with higher application of $\mathrm{N}$ fertilizer can cause nitrogen loss and $\mathrm{NO}^{3-} \mathrm{N}$ pollution of surface and ground water (Elmi et al., 2002; Stites and Kraft, 2001). Higher nutrient use efficiency under bed planting in various crops and cropping systems has also been reported by various researchers (Limon et al., 2000, Singh et al., 2002c).

\section{Water management}

Bed planting, being a water efficient technology may prove to be a boon for farmers in dry regions. In beds, water moves furrow to furrow into beds and also upward in to bed though evaporation and capillary action. In furrow water moves downward by gravity as well as lateral movement to the ridges. Therefore, in light soil bed is useful in avoiding the nutrient and water losses through deep percolation. The upward movement of water into bed may also cause accumulation of salts in the surface and may affect crop growth and needs special attention. In light textured soils having low water holding capacity and higher infiltration rates, generally irrigation through flooding method have high water losses in the form of evaporation and seepage resulting into low water, nutrient and other input use efficiencies. In bed due to compaction of soil by tractor tyre in furrows causes faster movement of water and also lesser area. So, small quantity of water can be applied over large area through bed planting and depending upon soil type water saving ranges from 20 to $40 \%$. Sharma et al. (2005), while studying effect of various tillage options on water economy reported irrigation water saving of $30.38 \%$ with bed over conventional tillage. Experimental results suggest irrigation water savings to the tune of 12 to $60 \%$ with similar or lower yields for direct seeded and transplanted rice on beds, compared to puddled flooded transplanted rice (Balasubramanian et al., 2003; Hossain et al., 2003). However, some studies show little effect of rice on beds on water productivity as the decline in water input was accompanied by a similar decline in yield (Singh et al., 2002a; Jehangir et al., 2002).
Increased water use efficiency and 35\% reduction in irrigation water requirement in wheat grown under bed planting in Mexico and improvement in yield by $10 \%$ with irrigation application in furrows as compared to flood irrigation was reported (Moreno et al., 1993 and Sayre, 2000). They also reported better utilization of solar radiation and less crop lodging with bed planting. Another advantage of the system is that additional irrigation during late grain filling stage can be made which generally results in lodging under flat system. Raised bed not only facilitate in efficient water usage but also drainage. Therefore, it helps in improving the yield under both dry and excessive wet conditions

Table 6. Irrigation water used under different crops in various planting methods

\begin{tabular}{|c|c|c|c|}
\hline \multirow[t]{2}{*}{ Crops } & \multicolumn{2}{|c|}{$\begin{array}{c}\text { Irrigation water use } \\
(\mathrm{cm})\end{array}$} & \multirow{2}{*}{$\begin{array}{l}\text { \% Saving } \\
\text { over flat } \\
\text { irrigation }\end{array}$} \\
\hline & Bed & Flat & \\
\hline Wheat & 27.63 & 33.42 & 17.32 \\
\hline Maize & 25.38 & 30.18 & 15.90 \\
\hline Pigeon pea & 12.69 & 15.03 & 15.56 \\
\hline Soybean & 16.92 & 20.12 & 15.90 \\
\hline Green gram & 16.92 & 20.92 & 15.90 \\
\hline Vegetable pea & 8.46 & 10.26 & 17.54 \\
\hline Mustard & 9.00 & 10.86 & 17.12 \\
\hline
\end{tabular}

Source: Tripathi (2008)

Bed planting system provided opportunity to reduce irrigation water requirement of the crops. The crops like wheat, maize, pigeon pea, soybean, green gram, vegetable pea and mustard were grown under bed and flat planting system. It was observed that crops grown under bed planting system require almost 15-17 \% lesser irrigation water compared to conventional planting system (Table 6). Results showed that bed planting technology could be utilized more efficiently in the areas where water is a scarce commodity.

\section{Weed management}

Growing of crops under bed technique reduces the intensity of weed to a great extent. Under this system, fertilizers are placed close to the plant roots that enhance crop's accessibility to nutrient and provide competitive edge over weeds. The higher use efficiency of fertilizer through better placement and faster drying of the top portion of beds is responsible for reduction of weed problems. Growing three rows of wheat on beds are better compared to 2 rows in reducing weed problem in wheat (Chhokar et al., 2002). Mechanical weeding in crops using tractor mounted interculture implement 
is possible under bed system. In case of wheat raised on beds consisting of 2 rows per bed, 40-45 DAS mechanical weeding can be done using tractor mounted interculture. The feasibility of mechanical weed control in this system ultimately reduces the dependency on the herbicides. The feasibility of pre-seeding irrigation in bed system allows the weed population to be controlled mechanically or through non-selective herbicides before crop seeding. This strategy along with mechanical weeding/interculture after crop emergence can provide effective control of weeds. Continuous adoption of ricewheat cropping system in the Northwest plains of India had been in favour of grassy weeds specially Phalaris minor.

Multiple herbicide resistance in this particular weed has been reported (Chhokar and Sharma, 2008). Farmers hit by resistance faced and faces complete crop failure at few places and wheat fields were frequently ploughed up or harvested as fodder. In absence of effective alternative herbicides the resistant biotypes continue to quickly expand their infestation area. The introduction of new resource conservation technologies like bed planting and zero tillage $(\mathrm{ZT})$ provides an opportunity to manage the weed population by use of pre plant herbicides options (Chhokar et al., 2012). It was observed that bed planting and ZT recorded lower weed dry weight than conventional tillage. Therefore, the planting methods like bed and ZT have significant role in reducing the population of weeds especially Phalaris minor in wheat. Continuous adoption of these technologies will provide an eco friendly and cost effective wheat cultivation.

\section{Soil properties}

Under bed planting, bulk density and soil penetration resistance of top layers remain lower than under conventional tillage mainly because of loose nature of top soil of beds. The lower bulk density means more porosity especially in upper surface (Table 7). With the passage of time the differences between soil physical parameters get narrowed (Aggarwal and Goswami, 2003) because height of bed gets reduced and become compacted. As a result of better physical environment (loose soil) under bed planting, higher root length density in upper $0-50 \mathrm{~cm}$ soil layer was observed than that of conventional tillage system. The adoption of permanent beds will lead to controlled traffic thereby providing a healthy root environment. Fine tilth and better aeration causing less penetration resistance are responsible for better root development thereby producing higher yield attributes. Higher yield recorded in bed planting can be attributed to better soil environment in ridges since prolonged ponding reduces yield (Tisdall and Hodgson, 1990).

Table 7. Effect of planting methods on soil properties at harvest and wheat yield

\begin{tabular}{|c|c|c|c|c|c|c|c|}
\hline \multirow[t]{2}{*}{ Planting methods } & \multicolumn{2}{|c|}{$\begin{array}{c}\text { Bulk density } \\
\left(\mathrm{Mg} / \mathrm{m}^{3}\right)\end{array}$} & \multicolumn{2}{|c|}{$\begin{array}{c}\text { Penetration resis- } \\
\text { tance }(\mathrm{MPa})\end{array}$} & \multicolumn{2}{|c|}{$\begin{array}{l}\text { Root length density at } \\
\text { harvest }(\mathrm{cm} / \mathrm{cm})^{3}\end{array}$} & \multirow[t]{2}{*}{$\begin{array}{r}\text { Yield } \\
(\mathrm{t} / \mathrm{ha})\end{array}$} \\
\hline & $0-10 \mathrm{~cm}$ & $10-20 \mathrm{~cm}$ & $0-10 \mathrm{~cm}$ & $10-20 \mathrm{~cm}$ & $0-25 \mathrm{~cm}$ & $25-50 \mathrm{~cm}$ & \\
\hline Bed planting (3R) & 1.50 & 1.62 & 0.36 & 0.78 & 6.37 & 1.16 & 5.31 \\
\hline Conventional & 1.53 & 1.65 & 0.38 & 0.82 & 4.85 & 1.87 & 5.09 \\
\hline
\end{tabular}

Source: Aggarwal and Goswami (2003)

\section{Bed planting an eco-friendly tillage option}

In recent time a lot of emphasis is given to those technologies that promote ecosystem and contribute least to pollution. Bed is an eco-friendly tillage option compared to conventional tillage. Even conventional field preparation followed by drill or bed planter sowing on bed results in reduction of $\mathrm{CO}_{2}$ emission (considering $2.6 \mathrm{~kg} \mathrm{CO}_{2}$ production/litre diesel burnt) by 18-19\% compared to broad cast sown (Sharma et al., 2007). Adoption of this technology saves about 40\% diesel. The saving is more under double no till bed planting as from second year onwards only reshaping and sowing is done. This technology also provides opportunity for nutrient cycling through residue management, green manuring etc. and thereby reduce fertilizer requirement. Due to increase in use efficiency of water and fertilizer, less water and fertilizer are required to produce same quantity of produce. Bed technology is also reported to reduce population of P. minor in wheat (Tripathi, 2008).

\section{Modern applications of raised bed cultivation}

There are numerous examples in modern agriculture that have applied raised bed cultivation to ameliorate problems created by excess water for both dry land and irrigated conditions. In dry land production systems in Australia, for example, the use of wide, raised beds (1.5 to $3 \mathrm{~m}$ wide depending on machinery) has been found 
to alleviate serious water logging following episodes of excess rainfall in Victoria whereas, in Western Australia wide, raised beds have proven useful where water logging occurs with even nominal rainfall on the prevalent, duplex soils which are characterized by extremely poor water infiltration. Yields for a wide variety of crops including wheat (Triticum aestivum L.), barley (Hordeum vulgare L.), canola (Brassica sp), lupins (Lupinus sp), faba beans (Vicia faba, L.) and oats (Avena sativa, L.) have been markedly increased compared to conventional flat planting. Where excess water is a problem and raised beds contribute to facilitating drainage. The width of the bed can be quite variable depending upon the methods used to form and maintain the beds (machinery, draft animal and or human labor) and on soil type to some extent.

At the other extreme of the moisture/rainfall spectrum is the use of raised beds in mainly semi-arid/arid regions to provide irrigation water by furrow irrigation. Farmers located in the Yaqui Valley in the state of Sonora in northwest Mexico provide an exceptional example of the application of raised bed cultivation with furrow irrigation over about 255,000 ha of irrigated land. Bed width ranges from $60-100 \mathrm{~cm}$, center bed to center bed and this narrower bed width facilitates the efficiency of furrow irrigation for most soil types (Aquino, 1998).The farmers that grow wheat on beds obtain about $8 \%$ higher yields, use about $25 \%$ less irrigation water and encounter at least $25 \%$ less operational costs as compared to those still planting conventional tilled wheat on the flat, using flood irrigation (Aquino, 1998).

\section{Possible impact}

Considering the large acreage under rice-wheat cropping system, the adoption of bed planting technology would save huge amount of natural resources. Rice - wheat system in IGP alone covers about $10.3 \mathrm{~m}$ ha. Even if 25 $\%$ of this area could be brought under bed, it would be possible to save about 90 million ha $\mathrm{cm}$ water (Considering a minimum of $20 \%$ water saving in rice and wheat and water requirement of rice and wheat as 1400 and $400 \mathrm{~mm}$, respectively). This amount of water could be sufficient for bringing additional 2 to 2.5 million hectare wheat area under irrigation. In this way the impact of this technology could be huge. Further, if the intensification, saving on labour cost, diesel, fertilizer etc. is considered, this technology seems to be much more sustainable.

\section{Future strategies}

The future of bed planting depends upon the development of low cost multicrop planter for various crops in system perspective. Adoption of bed would be more feasible for the cropping system where permanent beds can be maintained. Additionally, development of low cost machineries which will be capable of seeding of various crops and placing fertilizers into loose residue condition will play vital role in the forthcoming years. The approach would be by piercing through residue or cutting the residue and keeping in adjacent furrows or using residue as mulch. Utilizing the potential of bed planting technology for enhancing the productivity of crops will be of paramount significance. There is need also for tailoring of genotypes particularly wheat for different resource conservation technologies including beds.

In order to intensify wheat based systems and to increase resource use efficiency, bed-planting system holds a lot of promise. Bed planting with furrow irrigation not only improves water use efficiency but also enhances soil physical properties that provide a better condition for crop growth and development. The system facilitates easy intercultural operations as against other planting practices. The major benefit from bed planting is the tremendously enhanced field access, which facilitates controlling weed and other pests, handling nutrients, reducing tillage and managing crop residues. Adoption of this system increases the production of cereals, pulses, oilseeds and vegetables to a great extent.

\section{References}

1. Aggarwal P and B Goswami. 2003. Bed planting system for increasing water use efficiency of wheat grown on Inceptisol (Typic Ustochrept). Indian Journal of Agricultural Sciences 73(8): 422-25.

2. Aquino P. 1998. The adoption of bed planting of wheat in the Yaqui Valley, Sonora, Mexico. Wheat Special Report No. 17a. Mexico, DF: CIMMYT.

3. Balasubramanian V, JK Ladha, RK Gupta, RK Naresh, RS Mahela, B Singh and Y Singh. 2003. Technology options for rice in rice-wheat system in south Asia. P. 115-118. (In) Ladha et al.(ed.). Improving the productivity and sustainability of ricewheat systems: Issues and impact. ASA Spec. Pub. 65ASA, CSSA, and SSSA, Madison, WI. 
4. Cassman KG and PL Pingali. 1993. Extrapolating trends from long-term experiments to farmers fields: the case of irrigated rice systems in Asia. (In) Proceedings of the Working Conference on "Measuring Sustainability Using Long-Term Experiments." Rothamsted Experimental Station, 28-30 April 1993, funded by the Agricultural Science Division, The Rockefeller Foundation.

5. Chauhan DS, RK Sharma, AS Kharub, SC Tripathi and RS Chhokar . 2001. Effect of crop intensification on productivity, profitability, energetics and soil fertility in rice (Oryza sativa L.)-wheat (Triticum aestivum L.) cropping system of north-western plains. Indian Journal of Agricultural Sciences. 71(5) 299-302.

6. Chhokar RS, DS Chauhan, RK Sharma, RK Singh and RP Singh. 2002. Major weeds of wheat and their management. Research Bulletin No 13, Directorate of Wheat Research Karnal, 1-16.

7. Chhokar RS and RK Sharma. 2008. Multiple herbicide resistance in Littleseed canarygrass (Phalaris minor): A threat to wheat production in India. Weed Biology and Management. 8:112-123.

8. Chhokar RS, RK Sharma and Indu Sharma. 2012. Weed management strategies in wheat: A review. Journal of Wheat Research. 4(2):1-21

9. Connor DJ, RK Gupta, PR Hobbs and KD Sayre 2003. Bed planting in rice-wheat system. (In) Addressing resource conservation issues in ricewheat system of south Asia: A Resource Book. Rice-wheat consortium for the Indo Gangetic PlainsInternational Maize and wheat Improvement Center, New Delhi, India, 103-108.

10. Duxbury JM, IP Abrol, RK Gupta and KF Bronson. 2000. Analysis of long term soil fertility experiments with rice-wheat rotations in south Asia. (In) Abrol et al. (Eds.), Long-term Soil Fertility Experiments in Cropping Systems. Rice-Wheat Consortium for the Indo-Gangetic Plains, New Delhi, 7-22.

11. Elmi AA, C Madramootoo, M Egeh, A Liu and C Hamel. 2002. Environmental and agronomic implications of water table and nitrogen fertilization management. Journal of Environment Quality 31:18581867.
12. Gupta RK, RK Naresh, PR Hobbs, J Jheng and JK Ladha. 2003. Sustainability of post-Green Revolution agriculture: The rice-wheat cropping systems of the Indo-Gangetic plains and China. (In) J.K. Ladha, J. Hill, R.K. Gupta, J. Duxbury and R.J. Buresh. (eds) Improving the productivity and sustainability of ricewheat systems: issues and impact. ASA, Spec. Publ. 65. Chapter 1:1-25. ASA Madison, WI. USA.

13. Hegde DM. 1992. All india coordinated agronomic research project, Research Highlights. Project Directorate for Cropping Systems Research (PDCSR). Meerut, Uttar Pradesh, India,

14. Hobbs P and M Morris. 1996. Meeting South Asia`s future food requirements from rice-wheat cropping systems: priority issues facing researchers in the postgreen revolution era. 96-101. In Natural Resource Group Paper. Mexico: CIMMYT.

15. Hobbs PR and RK Gupta. 2003. Resource conserving technologies for wheat in rice-wheat Systems. (In) Ladha JK, J Hill, RK Gupta, J Duxbury and R Buresh $\mathrm{J}$ (eds) Improving the productivity and sustainability of rice-wheat systems: issues and impact. ASA, Spec. Publ. 65, chapter 7, 149-171. ASA Madison, WI. USA.

16. Hossain MI, MA Sufian, ABS Hossain, CA Meisner, JG Lauren and JM Duxbury. 2003. Performance of bed planting and nitrogen fertilizer under ricewheat-mungbean cropping systems in Bangladesh. Wheat Research Centre Internal Review Reports (Bangladesh Agricultural Research Institute, Dinajpur, Bangladesh).

17. Hulugalle NR, TB Weaver, LA Finlav, J Hare and PC Entwistle. 2007. Soil properties and crop yields in a dryland Vertisol sown with cotton-based crop rotations. Soil and Tillage Research. 93:356-369

18. Jat ML and SK Sharma. 2005. Crop diversification. (In)Agenda notes, 13th Regional Technical Coordination Committee Meeting of the RWC. Feb 6-8, 2005, Dhaka, Bangladesh. 19-20.

19. Jat ML, A Shrivastava, SK Sharma, RK Gupta, PH Zaidi, HK Rai and G Srinivasan. 2005. Evaluation of maize-wheat cropping system under double-notill practice in Indo-Gangetic basin of India. (In) 9th Asian Maize Research Workshop, September, 4-10, Beijing, China 
20. Jehangir WA, H Murray-Rust, I Masih and K Shimizu. 2002. Sustaining crop and water productivity in the irrigated rice-wheat systems. Paper presented at national workshop on rice-wheat cropping system management, Pakistan Agricultural Research Council Rice-Wheat Consortium for Indo-Gangetic Plains. December 11-12, Islamabad, Pakistan.

21. Joshi AK, R Chand and B Arun. 2004. A compendium of training programme on wheat improvement for eastern India and warmer regions of India: Conventional and non-conventional approaches. NATP project, ICAR, BHU, Varanasi, India.

22. Joshi AK, R Chand, B Arun, RP Singh and Ortiz Rodomiro. 2007. Breeding crops for reduced-tillage management in the intensive, rice-wheat systems of South Asia. Euphytica. 153:135-51.

23. Kleinhenz V, DJ Midmore and WH Schintzler. 1996. High bed systems for off-season vegetable production in the tropics and subtropics. Agricultural Rural Development 3:60-62.

24. Ladha JK, KS Fischer, M Hossain, PR Hobbs and B Hardy. 2000. Improving the productivity and sustainability of rice-wheat systems of the Indo-Gangetic Plains: A synthesis of NARS-IRRI partnership research. IRRI Disc. Paper. Series. No. 40. IRRI, Los Banos, Philippines.

25. Ladha JK, D Dawe, H Pathak, AT Padre, RL Yadav, B Singh, Yadvinder Singh, Y Singh, P Singh, AL Kundu, R Sakal, N Ram, A P Regmi, SK Sami, A L Bhandari, R Amin, C R Yadav, AM Bhattarai, RK Gupta and PR Hobbs. 2003. How extensive are yield declines in long-term rice-wheat experiments in Asia? Field Crops Research 81:159-180.

26. Limon OA, KD Sayre and CA Francis . 2000. Wheat and maize yields in response to straw management under a bed planting system. Agronomy Journal 92: 295-302.

27. Maynard M. 1991. Permanent beds - their potential role in soil management for the future. Farmers' Newsletter Large Area. 137: 14-18.

28. Moreno O, M Salazar, M Tamayo and J Martinez. 1993. Technologia para la produccion de trigo en surcos . Foll. Tecn. 22. SARH. INIFAP. Cd. Obregon. Sonara, Mexico.
29. Nambiar KKM and IP Abrol. 1989. Long term fertilizer experiments in India. An overview. Fertilizer Newes 34:11-20.

30. Powlson DS, PR Poulton and JL Gaunt. 1998. The role of long-term experiments in agricultural development. P. 1-15. (In) A. Swarup et al. (eds.) Proc. of a national workshop on long-term soil fertility management through integrated plant nutrient supply. Indian Institute of Soil Science, Bhopal, India,

31. Sayre KD and OH Moreno Ramos. 1997. Applications of raised-bed planting system to wheat, Wheat Special Report No. 31: 1-31. Mexico, D F, CIMMYT.

32. Sayre KD. 2000.Effects of tillage, crop residue retention and nitrogen management on the performance of bedplanted, furrow-irrigated spring wheat in northwest Mexico. Proceedings $15^{\text {th }}$ Conference International Soil Tillage Reserch. Fort Worth, Texas, USA.

33. Sayre KD. 2002. Management of irrigated wheat. (In) Curtis BC, S Rajaram, H Gomez Macpherson (eds) Bread wheat: Improvement and production. Food and Agriculture Organization, Rome, Italy, 395-406.

34. Sayre KD and PR Hobbs. 2004. The raised- bed system of cultivation for irrigated production conditions. (In) sustainable agriculture and the international rice-wheat system, Lal et al. (Eds): 337-55.

35. Sharma AK, GP Singh, J Rane and S Nagarajan. 1997. Alternate selection approaches for targeted cropping sequences. (In) Proceedings International group meeting wheat research needs beyond 2000 AD. Narosa publishing House, New Delhi, 227-31.

36. Sharma RK, SC Tripathi, AS Kharub, RS Chhokar, AD Mongia, J Shoran, DS Chauhan and S Nagarajan 2005. A decade of research on zero tillage and crop establishment. Research Bulletin No.18:1-36. Directorate of Wheat Research, Karnal, Haryana, India.

37. Sharma RK, RS Chhokar and S Chander. 2007. Resource conservation tillage technologies for sustainability and higher productivity of rice-wheat system. Journal of Wheat Research. 1(1\&2): 97-102.

38. Singh RP, SK Das, VM Bhaskar Rao and M Narayan Reddy. 1990. Towards sustainable dryland agricultural practices. Central Institute for Dryland agriculture, Hyderabad, 5-8. 
39. Singh AK, BU Choudhary and BAM Bouman 2002a. Effects of rice establishment methods on crop performance, water use and mineral nitrogen. (In) “Water-wise Rice Production' (Eds) Bouman BAM, H Hengsdijk, B Hardy, B Bindraban, Toung T P and Ladha JK 237-246. Proceedings of the International Workshop on Water-wise Rice Production, 8-11, April 2002, Los Banos, Philippines (IRRI, Los Banos, Philippines).

40. Singh B, PR Gajri, J Timsina, Y Singh and SS Dhillon. 2002b. Some issues on water and nitrogen dynamics in rice-wheat sequences on flats and beds in the Indo-Gangetic plains. (In) Modeling irrigated cropping systems, with special attention to rice-wheat sequences and raised bed planting. Humphreys E and Timsina J (Eds.) Proceedings of a Workshop, CSIRO Land and Water, Griffith, NSW, Australia, 25-28 February CSIRO Land and Water Technical Report 25/02.

41. Singh S, A Yadav, RK Malik and H Singh. 2002c. Furrow irrigated raised bed planting system: A resource conservation technology for increasing wheat productivity in rice-wheat sequence, 198200. (In) RK Malik et al. (Eds.) Herbicide resistance management and zero tillage in rice-wheat cropping system. Proceedings of International Workshop. Hisar, India, 4-6 March 2002. CCS HAU Hisar, India.

42. Stites W and GJ Kraft. 2001. Nitrate and chloride loading to ground water from an irrigated north central US sand plain vegetable field. Journal of Environment Quality 30: 176-84.

43. Timsina J and DJ Connor. 2001. Productivity and management of rice-wheat cropping systems: issue and challenges. Field Crops Research 69:93-132.

44. Tisdall JM and AS Hodgson. 1990. Ridge tillage in Australia: a review. Soil and Tillage Research 18: 27-44.

45. Trethowan RM and M Reynolds. 2005. Drought resistance: genetic approaches for improving under stress. (In) Proceedings of the 7th International wheat conference, 27 November-2 December Mar del Plata, Argentina.
46. Tripathi SC. 2008. Bed planting for higher return in rice-wheat system. Indian Farming 58(2): 18-21.

47. Tripathi SC and RP Singh. 2008. Effect of crop diversification on productivity and profitability of rice (Oryza sativa)-wheat (Triticum aestivum) cropping system. Indian Journal of Agronomy 53(1):27-31.

48. Tripathi SC, KD Sayre, JN Kaul and RS Narang. 2002. Effect of planting methods and $\mathrm{N}$ rates on lodging, morphological characters of culm and yield in spring wheat varieties. Cereal Research Communications 30(34): 431-38.

49. Tripathi SC, KD Sayre and JN Kaul. 2005. Planting systems on lodging behavior, yield components and yield of irrigated spring bread wheat. Crop Science 45(4) :1448-55.

50. Tripathi SC, S Chander and Meena Raj Pal. 2016. Intensification is the key for sustainability of ricewheat system productivity and profitability in India. International Journal of Tropical Agriculture 34(1):75-80.

51. Wang FH, SJ Liu, XQ Wang. 1999. Eco-physiological effect of bed-planting culture techniques. Shandong Agricultural Sciences 4: 4-7

52. Wani SP, OP Rupela and KK Lee. 1995. Sustainable agriculture in the semi-arid tropics through biological nitrogen fixation in grain legumes. Plant and Soil 174: 29-49.

53. Watt M, JA Kirkegaard and GJ Rebetzke. 2005. A wheat genotype developed for rapid leaf growth copes well with the physical and biological constraints of unplowed soil. Functional Plant Biology 32: 695-700.

54. Yadav RL, BS Dwivedi, KS Gangwar and K Prasad. 1998. Overview and prospects for enhancing residual benefits of legumes in rice and wheat cropping systems in India. In: Residual effects of legumes in rice and wheat cropping systems of the Indo-Gangetic Plain (Eds Kumar Rao, J V D K Johansen, C and Rego T J), 207-225. Patancheru: International Crops Research Institute for the Semi-arid Tropics. 